\title{
Lessons of Survival in Managing Economic and Banking Crises
}

\author{
Abdul Raoof Butt , Abdul Raoof* \& Mehmood-ul-Hassan ${ }^{* * * *}$
}

\begin{abstract}
Pakistan is enduring a serious economic downturn and facing the probability of the collapse of the banking and financial systems. The growth outlook is meek and risk of default is hanging over the head of the nation as a sword. Banking and financial institutions and economic systems of Pakistan like that of ASEAN and other crises hit countries, suffer from bad loans, political interference, corruption, declining exports, budget and trade deficits, internal and external debts, crashes of stock exchanges, currency mismanagement, and double digit inflation. While 'survival of the fittest' is ever a self-evident truth, the lessons of the rise and fall of nations are important for survival. In order to meet the challenge of survival, it may be crucial to learn the underlying causes that accounted for and understand the strategies and reforms that attempted to manage the economies of the countries suffering from the crises.
\end{abstract}

The banking and financial sectors play significant roles in the contemporary world of business and economic growth. They influence economic activities in the field of production and facilitate the distribution of financial resources in diverse and integrated ways. The experiences of developed countries such as the United States of America, Germany and U.K. clearly demonstrate that organised economic structures and sound banking and financial systems not only boost their macro and micro economies but also may save them from any sudden banking and financial crisis.

Economic and banking crises vividly illustrate the consequences of weak financial systems and inadequate macroeconomic policies. Many countries of the world faced crises in their economic and banking systems that tended to worsen the structure of their entire economies. Rapid trade, globalisation, financial integration of world economies and technological developments are considered as catalysts for the 'East Asian Crisis' that hit many Southern Asian countries especially and the rest of the world generally.

\footnotetext{
${ }^{*}$ Chairman Department of Economics, University of the Punjab, Lahore.

** Chairman Department of Business Administration, Deputy Chairman Research Division, Yang-En University, China.

${ }^{* * *}$ Officer National Bank of Pakistan.
} 
Economic and banking problems require major and expensive reforms in the banking systems. Often, the problems have domestic causes, such as weak banking supervision, superfluous political interference, inadequate capital, and bad loans. Weakness of banking systems is considered as the main cause of the East Asian, Mexican, and Swedish crises. The countries adopted diverse strategies in order to survive in the crises with different levels of successes. Their experiences of banking and financial reforms may be useful to the rest of the world in order to minimise the risks of any probable crisis. This study investigates economic and banking crises in East Asian countries, Mexico and Sweden and deduces the lessons of survival.

Economics, culture, environment, production systems, and financial institutions are connected with one another in a circular cause and effect relationship. The study indicates that the survival in part is in producing environmentally safe quality products, creating sound alliances with international communities and institutions, promoting sustainable growth patterns, and following balanced trade pursuits. Survival is in the vitality of our culture and in the potency of our ideals. It is very important to improve the standards of supervision, regulation, and transparency of financial systems. In this connection, a central bank may be given a free hand through more autonomy. Consolidation of the credit markets, liberalisation of interest rates, application of prudential regulations, and sensible administration of privatisation policies may be useful in order to avoid a banking and financial crisis in Pakistan. The beneficiaries of this study may include banking experts, policy makers, financial analysts, and associated students and teachers.

\section{Introduction}

Banking and economic crises have many causes and have effects on growth and the survival of countries. Notorious crises include the Great Depression of the 1930s, the U.S. exchange rate crisis of 1894-96, the British sterling and French franc crisis of the 1960s, and global debt crisis of the 1980s. Various methods have been tried to recover from the banking and economic crises of Mexico, Chile, Spain, Sweden, and then the recent crisis of East Asian economies (Lyle, 1998).

The main factors considered for the breakdown of financial and economic systems in South East Asian nations are financial oversight, sizable short-term international capital outflows, and untenable attempts to maintain dollar-pegged domestic currencies. The list of factors also include a slowdown in growth resulting from overvalued currencies relative to the Japanese Yen and the Chinese RMB, competition from China's expanded productive capacity, declining demand for semiconductors in 1996, and 
increasing current account deficits both absolutely and as a percentage of GDP (Demirguc, Asli and Enrica, 1998).

There has been extensive research on the role of the banking sector in the macro economy and its importance in propagating business cycles. In this connection, earlier studies include Bernanke (1983) on the Great Depression, Bernanke and Gertler (1995), King (1994), Kiyotaki and Moore (1997), and Allen and Gale (1997). These studies indicate that a stable banking sector can amplify the magnitude of the business cycle, facilitate overall economic expansion and sustain financial markets.

The countries of East Asia, Indonesia, Malaysia, the Philippines, Thailand, South Korea, Hong Kong, and Singapore have long been called "Asian tigers" because of their roaring economies. Their economies have been characterised by growth rates averaging over 8 per cent annually for the last two decades, per capita incomes rising over the last 30 years by extraordinary amounts, very high domestic savings rates, low budget deficits, and low inflation. Singapore's growth exceeded 10 per cent in 1993-94, South Korea was 9 per cent in 1994-95, and Malaysia and Thailand also averaged growth rates of over 7 per cent during this period (Khan, 1998). The growth rates of the Philippines, Indonesia, and Taiwan were 5.1 per cent, 7.6 per cent and 6.3 per cent respectively in 1995 (World Bank, 1995).

Table-1: Key Indicators: East Asia

\begin{tabular}{lcccccc}
\hline Country & $\begin{array}{c}\text { GDP } \\
\text { per } \\
\text { Capita }\end{array}$ & $\begin{array}{c}\text { GDP } \\
\text { per } \\
\text { Capita }\end{array}$ & $\begin{array}{c}\text { Average } \\
\text { Annual } \\
\text { Rate of } \\
\text { Inflation }\end{array}$ & $\begin{array}{c}\text { Average } \\
\text { Annual } \\
\text { Rate of } \\
\text { Inflation }\end{array}$ & $\begin{array}{c}\text { Export } \\
\text { /GDP }\end{array}$ & $\begin{array}{c}\text { Export } \\
\text { /GDP }\end{array}$ \\
\hline & $\mathbf{( \$ )}$ & $\mathbf{( \$ )}$ & $\mathbf{\%}$ & $\mathbf{\%}$ & $\mathbf{\%}$ & $\mathbf{\%}$ \\
\hline South Korea & 1,520 & 9,700 & 19.8 & 6.7 & 34 & 33 \\
Philippines & $\mathbf{1 9 8 0}$ & $\mathbf{1 9 9 5}$ & $\mathbf{1 9 7 0 - 8 0}$ & $\mathbf{1 9 8 5 - 9 5}$ & $\mathbf{1 9 8 0}$ & $\mathbf{1 9 9 5}$ \\
Malaysia & 1,620 & 3,890 & 7.5 & 7.6 & 58 & 96 \\
Thailand & 670 & 2,740 & 9.9 & 5.0 & 25 & 42 \\
Indonesia & 430 & 980 & 20.5 & 8.8 & 33 & 25 \\
Japan & 1,980 & 1,995 & 7.5 & 1.4 & 14 & 9 \\
Singapore & 4,430 & 26,730 & 5.1 & 3.9 & 207 & - \\
\hline
\end{tabular}

Source: World Bank (1982) and World Bank (1995) 
Table-2: Saving and Investment: East Asia

\begin{tabular}{lcccc}
\hline \multicolumn{5}{c}{ Per cent of GDP } \\
\hline Country & $\begin{array}{c}\text { Gross } \\
\text { Domestic } \\
\text { Saving }\end{array}$ & $\begin{array}{c}\text { Gross } \\
\text { Domestic } \\
\text { Saving }\end{array}$ & $\begin{array}{c}\text { Gross } \\
\text { Domestic } \\
\text { Investment }\end{array}$ & $\begin{array}{c}\text { Gross } \\
\text { Domestic } \\
\text { Investment }\end{array}$ \\
\hline South Korea & $\mathbf{1 9 8 0}$ & $\mathbf{1 9 9 5}$ & $\mathbf{1 9 8 0}$ & $\mathbf{1 9 9 5}$ \\
Philippines & 25 & 36 & 32 & 37 \\
Malaysia & 24 & 15 & 29 & 23 \\
Thailand & 33 & 37 & 30 & 41 \\
Indonesia & 23 & 36 & 29 & 43 \\
Japan & 37 & 36 & 24 & 38 \\
Singapore & 31 & 31 & 32 & 29 \\
\hline
\end{tabular}

Source: World Bank (1997), World Bank (1982) and Asian Development Bank (1997-98).

The initial business gains led domestic and foreign investors to underestimate the countries' inherited economic weaknesses. Large financial inflows overwhelmed the policies and institutions of these nations. Money went through loans and investments, into unneeded and unproductive real estate and corporate expansion programmes (Wolf, 1998, March 3). The disguised unfeasible decisions slowly yielded bubbles of huge disruptive prices, inefficient companies and surplus buildings. International agencies tried to rescue the suffering countries from a deep depression. The IMF-led rescue package this time totalled over $\$ 113$ billion (Lissakers, 1988, October 8 ) and total lending from the World Bank was $\$ 18$ billion (World Bank, 1998).

Table-3: Total External Loan to East Asian Countries February, 1998 to February, 1999

\begin{tabular}{lrr}
\hline \multicolumn{3}{c}{ Total external loan } \\
\hline \multicolumn{1}{c}{ Country } & Year-1998 & \multicolumn{1}{c}{ Year-1999 } \\
\hline Indonesia & 703.20 Million & 1.65 Billion \\
Korea & 5.00 Billion & 2.48 Billion \\
Thailand & 38.00 Million & 700.00 Million \\
\hline
\end{tabular}


Asia's banking systems are the legacy of years of bad lending practices and inadequate supervision and regulation that led to rapid lending growth and excessive risk taking (Stijn \& Thomas, 1997). There was a collapse in currency values after a period of turmoil in foreign exchange markets. Asset values declined sharply and economic activity became negative. The crisis occurred at great economic cost in these countries in terms of output, investment and jobs (Shelby \& Davis, 1997). The banking and economic crisis in Southeast East Asian countries first affected Thailand, and then rippled outward to Indonesia, Hong Kong, Taiwan, and Korea. It also cast its shadow on Japan.

In 1997, more than $\$ 100$ billion of Asia's hard currency reserves had been transferred (in a matter of months) into foreign countries (South China Morning Post, 1997), such as Thailand, Malaysia, and the Philippines that approximated over $\$ 600$ billion, or about 60 per cent of their combined pre-crisis GDP (Stiglitz, 1998). Chinese economies also suffered badly as a result of the crisis. The total bad loans of China were RMB 6.173 billion in 1994 (Mehran, 1996) and total internal and external debt of Korea was $\$ 153$ billion in 1997 (Choi, 1997). Thailand's foreign debt rose to 50 per cent of GDP, of which 80 per cent was private-sector borrowing (The New York Times, 1999, March 19).

Table-4: Growth Rates of Selected Asian Countries

\begin{tabular}{lrcc}
\hline \multicolumn{4}{c}{ Crisis } \\
Country & $\begin{array}{c}\text { Per Capita } \\
\mathbf{1 9 9 6}\end{array}$ & $\begin{array}{c}\text { Annual } \\
\text { Average \% } \\
\mathbf{1 9 7 0 - 1 9 9 6}\end{array}$ & $\begin{array}{c}\text { Forecast } \\
\mathbf{1 9 9 8 \%}\end{array}$ \\
\hline Indonesia & 4,280 & 6.8 & -5.2 \\
South Korea & 12,410 & 8.4 & -2.5 \\
Thailand & 8,370 & 7.5 & -4.0 \\
Malaysia & 9,730 & 7.4 & 1.6 \\
Philippines & 360 & 3.6 & 1.9 \\
Singapore & 25,650 & 8.2 & 2.7 \\
China & 3,120 & 9.1 & 6.3 \\
Taiwan & 17,720 & 8.3 & 5.0 \\
\hline
\end{tabular}

Source: Institute of International Finance (1998). 
Table-5: Selected External Financing Measures for Five Asian Countries: South Korea, Indonesia, Malaysia, Thailand and Philippines

\begin{tabular}{lccccc}
\hline Factor/Year & $\begin{array}{c}\text { (Billions } \\
\text { of } \\
\text { Dollars) } \\
\text { US\$ }\end{array}$ & $\begin{array}{c}\text { (Billions } \\
\text { of } \\
\text { Dollars) } \\
\text { US\$ }\end{array}$ & $\begin{array}{c}\text { (Billions } \\
\text { of } \\
\text { Dollars) } \\
\text { US\$ }\end{array}$ & $\begin{array}{c}\text { (Billions } \\
\text { of } \\
\text { Dollars) } \\
\text { US\$ }\end{array}$ & $\begin{array}{c}\text { (Billions } \\
\text { of } \\
\text { Dollars) } \\
\text { US\$ }\end{array}$ \\
\hline \multicolumn{1}{c}{ Year } & $\mathbf{1 9 9 4}$ & $\mathbf{1 9 9 5}$ & $\mathbf{1 9 9 6}$ & $\mathbf{1 9 9 7}$ & $\mathbf{1 9 9 8}$ \\
\hline $\begin{array}{l}\text { Current A/C } \\
\text { Balance }\end{array}$ & - & 41.3 & -54.9 & -26.0 & 17.6 \\
$\begin{array}{l}\text { Net Private } \\
\text { Capital Flow }\end{array}$ & 40.5 & 77.4 & 93.0 & -121.1 & -9.4 \\
$\begin{array}{l}\text { Equity } \\
\text { Investment }\end{array}$ & 12.2 & 15.5 & 19.1 & -4.5 & 7.9 \\
$\begin{array}{l}\text { Commercial } \\
\text { Bank Loans }\end{array}$ & 4.2 & 12.4 & 18.4 & 13.7 & -3.2 \\
\hline
\end{tabular}

Source: Institute of International Finance (1998).

\section{Origin of the Banking and Financial Crisis}

In 1997-98, the economies of some Asian countries, popularly known as the Asian Tigers, suffered a serious setback. Stock markets crashed drastically, companies fell, banks collapsed and growth rates declined (Nizamani, 1999, October 4). Domestic mismanagement, corruption and the politicisation of loans through an unaccountable and non-transparent banking system played a central part. Over-borrowing in dollars in relation to foreign currency reserves, left companies and the banking systems exposed to the effects of interest rate rises and currency devaluation (Kaminsky \& Carmes, 1996).

A number of factors are alleged to have triggered the crisis. The list of factors include a weak financial system, massive non-forming loans, oversight, surging international capital flows, untenable attempts to maintain dollar-pegged domestic currencies, and a slowdown in growth resulting from overvalued currencies and increased competition from China's expanded productive capacity (McCall, 1998, April 27). China's 1994 currency devaluation undercut the export competitiveness of the crisis countries particularly Thailand and Indonesia, and was one of the contributing causes of the Asian crisis (Davies, 1998). 


\section{Table-6: Currency Depreciation against US Dollar (June 1997 - May 1998)}

\begin{tabular}{lc}
\hline \multicolumn{1}{c}{ Country } & Depreciation (\%) \\
\hline South Korea & 38.0 \\
Philippines & 37.9 \\
Malaysia & 38.2 \\
Thailand & 44.6 \\
Indonesia & 83.5 \\
Japan & 21.2 \\
Singapore & 18.3 \\
\hline
\end{tabular}

Source: Asia Week (1998, June 26).

The sudden currency devaluations of Thailand, Korea, the Philippines and Indonesia began in July 1997 when foreign investors started demanding their dollar-denominated loans. Banking policies and practices have been limited to narrow segments of economic development in the ASEAN region (Caprio \& Gerard, 1997).

Asian governments utilised the banking system to direct funds into favoured investments and toward favoured investors in order to fulfill their own selfish ends. Interest rate ceilings, government-directed lending and closed relationships between banks and borrowers destabilised the financial health of the countries. Unfeasible commercial bank credits had risen from $\$ 23$ billion in 1994 to $\$ 56$ billion in 1996 and $\$ 83$ billion in 1997 (Poon, 1998).

Experience shows that in an inexorable banking crisis such as that of the East Asian countries, depositors, lenders to banks, and owners of bank capital, all lose confidence and simultaneously seek to salvage their resources by withdrawing them. A single bank can fail without national repercussions, but when a large proportion of the deposits in a national banking system are involved, the problem becomes systemic and paralysis threatens the entire economy. The collapse of BCCI, Barings Bank, Daiwa Bank, Taj Company, Sachon Bank, Mehran Bank, and Banker's Equity Limited are but examples of the systemic paralysing phenomena (Baker, 1998). The governments have no option but to act. As always said, everything in this world has a price. The remedies available in a crisis are difficult and costly. The bubble of the crisis may be managed at costs but sometimes the roots are still alive and may hit like a hurricane later. 
The crisis in the ASEAN economies is perhaps the most serious banking and economic crisis since the collapse of the Bretton Woods system in the early 1970s, in terms of both its scope and its effects. Its impact is much more global than that of the financial crises we have seen in the past two or three decades, including those in Latin America (Goldstein \& Philip, 1996).

The banking and economic crisis of East Asian countries was the result of multi dimensional complicated but interrelated flaws in the banking and financial structure especially in the case of Korea. Other factors included permissive international capital markets, savings and investments imbalances in the private sector, real estate speculation in the case of Japan and Thailand, the nature of Asia's political economy, and finally the crash of the market in the mid-1990s, all contributed to the crisis. The Malaysian PM Mahathir, blamed international foreign exchange speculators for the incidence of the crisis (Nizamani, 1999, October 4).

Unlike in the United States, governments in Asia are more involved in business development (Poon, 1998). This reliance on more personalised and a cozy relationship based transaction increases the potential for corruption. That was one of the reasons of the crisis. The critical turn in the global economic environment caused an economic downturn in the case of Japan. The situation worsened with the increasing internal debt and nonperforming loans of major banks totalling about 44 trillion yen or $\$ 360$ billion (Toole, 1999, March 17). Massive capital flight in the case of Malaysia, inadequate legal structure, under developed securities markets, practices of unsound central banking, high interest rates and currency exposures, certainly in Korea, probably in Thailand and elsewhere, and large debt to equity leverage ratios appear to be the triggering factors for the crisis. Weaknesses in regulation and lax banking practices as in the obvious cases of Malaysia and Indonesia magnified the crisis (Marcus, 1997).

The governments of the ASEAN countries took serious measures to deal with the crisis. Thailand reduced reserve requirements, eased the rules governing non-bank financial institutions, expanded the scope of permissible capital market activities such as allowing banks to finance equity purchases on the margin, and increased access to off-shore borrowing. 'Korea eliminated many interest rate controls, removed restrictions on corporate debt financing and cross-border flows, and permitted intensified competition in financial services (Shirazi, 1998). The famous Bank Bali Scandal in Indonesia worth US\$80 million is the prime example indicating basic flaws and a loose concept of supervision and regulations in the banking system of Asean countries (Belchere, 1999). 


\section{Table-6: Non-Performing Loans across Countries}

\begin{tabular}{ll}
\hline \multicolumn{1}{c}{ Country } & Non-Performing Loans \% \\
\hline Indonesia & 75 per cent of GDP : 1998-99 \\
Thailand & 44 per cent of GDP : 1998-99 \\
Malaysia & 19 per cent of GDP : 1998-99 \\
\hline
\end{tabular}

Source: The News, (1999, September 8).

In these countries, day to day banking business was done on the basis of personal relationships and there was a lack of transparency in the overall banking and financial transactions especially in the case of Thailand (Moegan, 1998). Some critics observed that lending ratios of 80-100 per cent (20 per cent in Japan) and high to very high corporate risks (Indonesia, Thailand, South Korea) were also the causes of turbulence in the ASEAN economies.

In the absence of effective steps to counter the currency pressure, international commercial and investment banks, along with domestic investors seeking to limit their foreign currency exposure, withdrew support for these currencies. Between early July and mid-October, 1997, the currencies of Thailand and Indonesia had fallen 30 per cent relative to the dollar. Poor financial disclosure and underdeveloped securities markets, speculative investment in assets (Japan) rather than in productive channels and fragile financial structures (Philippines) are the main reasons for that vicious circle in which the banking crisis aggravated the corporate crisis (Caprio, Gerard and Klingebie1, 1996). Also there were very high current accounts deficits before the crisis in the East Asian countries. Loan defaults furthered the disastrous banking crisis in East Asian countries (Hudson \& Bill 1998, August 12). The crisis caused currencies to depreciate, share prices to drop, and interest rates to soar in Korea, the Philippines, Thailand, and Malaysia.

Table-8: External Current Account Deficits before Crisis

\begin{tabular}{lccc}
\hline Country & $\begin{array}{c}\text { 1995 (Per cent } \\
\text { of GDP) }\end{array}$ & $\begin{array}{c}\text { 1996 (Per cent } \\
\text { of GDP) }\end{array}$ & $\begin{array}{c}\text { 1997 (Per cent } \\
\text { of GDP }\end{array}$ \\
\hline Korea & -3.3 & -3.3 & -2.9 \\
Philippines & -4.4 & -4.7 & -4.5 \\
Thailand & -8.0 & -7.9 & -3.9 \\
Malaysia & -10.0 & -4.9 & -5.8 \\
\hline
\end{tabular}

Source: $\operatorname{IMF}(1998)$. 
Table-9: Changes in Currency Value, Share Price Index and Interest Rates July 1, 1997 to February 16, 1998

\begin{tabular}{lccc}
\hline Country & $\begin{array}{c}\text { Depreciation of the } \\
\text { currency vis-à-vis the } \\
\text { Dollar (Per cent) }\end{array}$ & $\begin{array}{c}\text { Changes in the } \\
\text { share price index } \\
\text { (Basic Points) }\end{array}$ & $\begin{array}{c}\text { Changes in the } \\
\text { interest rates } \\
\text { (Basic Points) }\end{array}$ \\
\hline Philippine & 51.37 & -49.17 & 0.00 \\
Indonesia & 231.00 & -81.74 & 2,398 \\
Korea & 83.04 & -63.06 & 965 \\
Malaysia & 55.43 & -58.41 & 373 \\
\hline
\end{tabular}

Source: Blooming Financial Services LP (1999).

\section{Role of Multinational Companies}

Multinational corporations have been carrying out business in South East Asia since the second half of the 1980s. They are alleged to cause structural imbalances in ASEAN economies and intensified socioeconomic contradictions. In 1995 , East Asian countries in the region received an estimated $\$ 108$ billion in foreign capital flows, of which $\$ 98$ billion was from private sources, including $\$ 54$ billion in direct investment of multinational companies (World Bank, 1995). Simultaneous pursuit by several countries of export-oriented growth inherently led to situations of excess capacity, intensifying pressure on wages and living standards, as well as increasing vulnerability to potentially destabilising currency fluctuations that were the outcome of unplanned foreign investment in all these countries. A sudden, unexpected and large-scale reversal of international capital flows out of ASEAN economies caused a serious economic situation in the subject countries (Stiglitz, 1998). Attempting to rescue the economies, during 1996, private foreign investors put $\$ 93$ billion into the ASEAN region (IMF, 1998, October).

Table-10: Capital Inflow in East Asia (1987-96)

\begin{tabular}{lcc}
\hline \multicolumn{1}{c}{ Country } & $\begin{array}{c}\text { Net Capital Inflow } \\
\text { (Average Annual }\end{array}$ & $\begin{array}{c}\text { Percentage of Capital Inflow to } \\
\text { GDP (Average Annual) }\end{array}$ \\
\hline South Korea & 80 & 5.1 \\
Thailand & 75 & 7.4 \\
Indonesia & 68 & 5.7 \\
Malaysia & 68 & 12.0 \\
Philippines & 23 & 4.3 \\
\hline
\end{tabular}

Source: Asian Development Bank (1999). 
Investors from the U.S., Western Europe and Japan poured capital into the region in the form of both bank loans and equity investments. The magnitude of the foreign capital inflows helped fuel a surge in domestic asset prices, particularly that of real estate (The Economist, 1999, October 2). Owing to massive industrialisation and direct involvement of foreign investment made by the multinational companies in the East Asian countries, traditional industries such as agriculture, and cotton and cottage industries have been replaced with golf courses and luxury hotels (Thailand), commercial property (Indonesia, Thailand, Malaysia), and steel, ships, semiconductors, and cars (Korea) (Bhagwati, 1998, March 25). There has been an increase in share investment (Japan) and margin lending to share investors (Japan, Malaysia, Korea, and Thailand). Massive industrialisation by foreign investors produced environmental destruction. The Institute of International Finance estimates that net private capital flows to Indonesia, Korea, Malaysia, the Philippines, and Thailand had increased from US\$38 billion in 1994 to \$97 billion in 1996 (Sharizi, 1998).

There has been a trend of conversion of production channels into a bubble economy. Income disparities between the people have widened so much that they have been divided into two groups with a handful of the rich on the one hand, and a great majority suffering from unemployment and poverty on the other. Consequently, the ASEAN economies have come to face insufficient domestic demand, decline of competitive ability due to a rise in personnel expenses, decline in savings, slowing of export growth, speculation in real estate, frequent occurrence of labour disputes, ethnic riots, political instability, corruption, massive capital flight, and unstable currency rates. Speculation in currency management, structured control over all productive channels, the philosophy of maximisation of profits, and concealed colonialism schema caused by the multinational companies had an adverse effect on the overall financial and banking assets of these countries. The crisis has driven the subject countries back many years in terms of development and probably created something like 12 to 15 million additional absolute poor in this region (International Labour Organisation, 1998, April).

Excessively rapid financial liberalisation and unrestrained role of multinational companies, foreign banks, consumers' services agencies and production plants can, in fact, undermine the optimal functioning of financial systems, thereby reducing growth and productivity. In some ways the business pursuits of multinationals are the main factors that hinder Asian nations from achieving autonomous industrialisation. Multinationals thrive on the dependency of nations upon the import of machinery and products from abroad. The pursuits of multinational companies have sometimes become an obstacle for Asian countries in building a well- 
balanced and independent industrial infrastructure that can boost overall macro economic expansion, solidity of the banking industry, productivity of the financial sector, sustained employment level, and inflation and ultimately produce stability in monetary management.

The crisis has exposed the inherent instability of the global market economy and the devastating impact of panic behaviour and large-scale shift of funds out of domestic financial markets by the foreign multinational companies and other corporations. Unfortunately in their pursuit of the growth objective, the policy makers and business managers ignored the difficulties stemming from the over-heating of the economy and over capacity production. There were false indications of pressures on resources as reflected in increasing real estate and equity markets. Consequently, the stock markets collapsed and massive foreign capital outflow encouraged speculation against the local currency (Haque, 1998).

Again, while the fiscal conditions may not have been a direct cause of concern, the excessive growth of financial system credit for the private sector resulted in high demand pressures. Standards of loan appraisal and portfolio management were generally inadequate and poorly enforced (Aziz, 1998, May 27). Saleem (1998, January 12-18) indicated that the large-scale increase in private sector credit was attributable to massive credit funds flowing directly into banking systems, yielding superficial escalation of foreign exchange reserves and the expansion of commercial bank liquidity and solvency. High domestic interest rates by international standards and relatively fixed exchange rates stimulated excessive foreign borrowing and hence easy availability of credit. All these are supposed to be important interrelated factors in the severe economic and banking crises across the global scene.

\section{Cost of the Crisis}

The ASEAN banking and financial crisis is one of the worst in modern history. It caused a restoration cost needed for a troubled banking system, ranging from 20 per cent of one year's GDP in Indonesia, Malaysia, and Japan to 30 per cent in Korea and Thailand. (Asian Financial Markets 1998, April 24). Only Chile in the 1980s with 33 per cent and Kuwait 45 per cent following the Iraqi invasion in 1990 had restoration costs greater than the ASEAN countries (Latin American Weekly Report, 1996, July 25). America's saving and loan crisis, by comparison, had a recapitalisation cost of 4-5 per cent of GDP over 1984-91 (Gart, 1993) and that of Mexico's crisis represented 12-15 per cent of GDP over 1995-97 (Financial Times, 1996, October 28). 


\section{Table-11: Fiscal Costs of Selected Banking Crisis Countries Percentage of GDP}

\begin{tabular}{lc}
\hline \multicolumn{1}{c}{ Country (Date) } & Cost (Percentage of GDP) \\
\hline Argentina (1980-82) & 55.3 \\
Uruguay (1981-83) & 31.2 \\
Spain (1977-85) & 16.8 \\
Bulgaria (1990s) & 14.0 \\
Hungary (1991-95) & 10.0 \\
Finland (1991-93) & 8.0 \\
Sweden (1990) & 6.4 \\
Norway (1987-89) & 4.0 \\
Cote d'Ivoire (1998-91) & 25.0 \\
Senegal (1988-91) & 17.0 \\
\hline
\end{tabular}

Source: Caprio and Klingebie1 (1996).

Experience has validated that a sound banking system and macroeconomic stability go together. For this reason, the occurrence of major banking failures throughout the world has been a matter of great importance for anyone concerned with the stability and prosperity of the world economy (Fischer, 1998, September 10). The closure of deeply insolvent financial institutions was a prominent feature of the programmes in Korea, Indonesia and Thailand. The Thai authorities suspended 16 finance companies in June 1997 and a further 42 in August 1997. All but two of these were closed permanently in December 1997. In Indonesia, 17 small banks were closed in November 1997 and in April 1998 another 7 small banks were closed. In Korea, 14 merchant banks were closed between December 1997 and April 1998 (Jeeman \& Won, 1997).

\section{Economic and Social Distress}

The crisis produced social distress and economic adversity in the suffering countries. Major banks was liquidated and consumers suffered from a price hike (Table-10). 
14 The Lahore Journal of Economics, Vol.4, No.2

Table-10: Indicators of Economic and Social Distress: Indonesia

\begin{tabular}{|c|c|c|c|}
\hline Country & Unemployment & $\begin{array}{c}\text { Business } \\
\text { Conditions }\end{array}$ & Social Conditions \\
\hline Indonesia & $\begin{array}{l}\text { Doubles to } 10 \% \\
\text { since } 1996 \text { Expected } \\
\text { to rise from } 8.5 \% \text { to } \\
\text { over } 11 \text { million this } \\
\text { year }\end{array}$ & $\begin{array}{l}\text { Government } \\
\text { Liquidated } 16 \\
\text { major banks } \\
\text { throwing much of } \\
\text { private sector into } \\
\text { technical } \\
\text { bankruptcy. }\end{array}$ & $\begin{array}{l}\text { Rioting to } \\
\text { protest food and } \\
\text { medicines } \\
\text { shortage } \\
\text { Consumer prices } \\
\text { up } 30 \% \text { for many } \\
\text { years. }\end{array}$ \\
\hline Korea & $\begin{array}{l}\text { Projected to be } \\
6.3 \% \text { in } 1998 \\
\text { Record of } 1.2 \\
\text { million already } \\
\text { jobless } 12 \text { of top } 30 \\
\text { conglomerates wish } \\
\text { to downsize by } 20- \\
50 \% \text { (Chamber of } \\
\text { Commerce and } \\
\text { Industry Survey). }\end{array}$ & $\begin{array}{l}\text { One third of } \\
\text { merchant banks } \\
\text { closed } 15-12 \% \text { of } \\
\text { banks's loans } \\
\text { non-performing. } \\
\text { Small enterprise } \\
\text { bankruptcies } \\
\text { tripled in January. }\end{array}$ & $\begin{array}{l}\text { Government } \\
\text { forced to triple } \\
\text { funds for } \\
\text { unemployment } \\
\text { and insurance. } \\
\text { Inflation } \\
\text { expected to be } \\
\text { more than } 10.5 \% \\
\text { in } 1998 \text {. }\end{array}$ \\
\hline Thailand & $\begin{array}{l}\text { Increased by more } \\
\text { than } 700,000 \text { since } \\
\text { crisis began } \\
\text { Expected to reach } \\
5.6 \% \text { a record two } \\
\text { millions jobless by } \\
\text { the end of year } \\
300,000 \text { Burmese } \\
\text { have been deported } \\
\text { to ease employment } \\
\text { situation }\end{array}$ & $\begin{array}{l}56 \text { finance } \\
\text { companies with } \\
\$ 20 \text { billion in } \\
\text { assets forced to } \\
\text { close. }\end{array}$ & $\begin{array}{l}\text { Consumer prices } \\
\text { up } 9.5 \% \text { year- } \\
\text { over year. } \\
\text { Farmers } \\
\text { demonstrated for } \\
\text { more grant and } \\
\text { aid. }\end{array}$ \\
\hline
\end{tabular}

Source: Steams, International Labour Organisation, International Monetary Fund, and Institute of International Finance (1998).

\section{Impact on the Rest of the World}

Today, global financial integration is universal and the East Asian countries have a significant share of world trade and production. For the first time, a financial crisis in the South has had a profound impact on 
capital markets in the North. It is considered to cause a momentous drop in global growth. It badly rocked many South American countries, which now face the prospects of turmoil in stock markets and currency problems that could eventually be on the scale of Southeast Asia. On 30 October 1997, Brazil's stock market index plunged 9.8 per cent and the level fell 23 per cent over five days. The Brazil Central Bank spent over US\$5 billion to defend its currency. Also affected are Argentina and Mexico, whose stock markets also dropped 9.1 and 3.4 per cent respectively on 30 October. It decreased by $\$ 260$ billion in the European Union (3.25 per cent of GDP), \$210 billion in Japan ( 5 per cent of GDP), and $\$ 40$ billion in the U.S. ( 0.5 per cent of GDP) (International Monetary Fund, 1998).

The Asian crisis reduced the exports and imports flows to and from the U.S.A., Canada and Europe and the net loss exceeded $\$ 700$ billion of which more than $\$ 30$ billion was lost by U.S. investors (Johnson, Ellis and Stiff, 1998). European banks had the greatest exposure and their losses were projected at more than $\$ 20$ billion. For example, Deutsche Bank took a charge of $\$ 773$ million against 1997 earnings to cover its more than $\$ 5$ billion in loans to East Asia (Stearns, 1998, April 14). The IMF (1998, April) estimated that world growth might be cut by 3 per cent in 1998 due to the Asian crisis.

Western industrial countries are expected to see only about a half per cent reduction in growth as a result of the ASEAN crisis (Roach, 1998, February). Two-fifths of all U.S. agricultural shipments go to Asian markets. Among the manufacturing sectors, the production and trade of computers, semiconductor equipment, industrial machines, power generating equipment, aircraft engines, and appare1 will be most affected (U.S. Department of Commerce, 1998). One study suggests that 700,000 manufacturing jobs could be lost per $\$ 100$ billion deterioration in the merchandise trade deficit (Scott \& Rothstein, 1998).

The recent East Asian economic and banking crisis, which erupted in July 1997, has produced effects of varying proportions on the economies of several other countries including advanced industrial economies. It hurt investor sentiment towards growing market economies and led to large-scale currency depreciations in the countries of the region. It will dampen economic activity in the fastest growing region with significant implications for the employment situation, at least in the short run (Khan, 1998, pp.3-6). Due to that severe economic and banking crisis, there was an overall negative impact on the growth rates of all the others countries of the world. After the overwhelming crisis there was a huge withdrawal of international capital and severe credit tightening 
which ultimately jeopardised all economic activities in the entire region. World output growth slowed to 2.5 per cent in 1998 mainly due to the ASEAN economic crisis (IMF, 1999, May).

\section{Reforms in Banking and Financial Systems}

Banking and financial reforms are indispensable in order to avoid the sudden and frequent phenomenon of a banking and financial crisis. They will restore the solvency and profitability of banks and financial institutions and hence ensure the survival of a nation. The reforms may improve the overall capacity of banking and economic systems to provide complete financial intermediation between savers and borrowers and ultimately restore public confidence (Dziobek \& Pazarbasioglu, 1997). Experience has validated that a sound banking and economic system and macroeconomic stability go hand in hand. For this reason, the occurrence of major banking failures throughout the world has been a matter of great importance for anyone concerned with the stability and prosperity of the world economy. (Fischer, 1998, September 10).

\section{Strategies and Reforms}

- Grant of autonomy to the central bank as sole restructuring agency (Almost every affected country of East Asia gave full autonomy to their central banks).

- Liquidity support by central banks (Japan, China, and Korea).

- Closure of insolvent banks and unprofitable financial institutions (Thailand, Philippines, and Malaysia).

- Write down of shareholders' capital (Singapore, Indonesia).

- Establishment of agencies for restructuring and restoration of banks and other financial institutions.

- Improvement of supervisory and regulatory systems (Japan, Korea, Singapore, Philippines).

- Increasing the chances for foreign participation in domestic financial systems in a legalised manner with vigilant supervision and strict regulation.

- Merger of insolvent banks (Thailand, Singapore, and Japan). 
- Privatisation (where applicable) in order to reduce undue deficit financing through external/internal debt (Thailand, Philippines, Indonesia, Malaysia).

- Enterprise restructuring to improve creditors (Japan, Korea, Philippines).

- Alliances with foreign banks in the cases of Indonesia, Malaysia, Philippines, and Thailand (Dewatripont \& Tirole, 1994; Goldstein \& Philip, 1996; Jeeman \& Won, 1997; Kaminsky \& Carmes, 1996; and Toole, 1999, March 17).

Table-12: Institutional Development: Thailand, Indonesia and Korea

\begin{tabular}{ccll}
\hline Country & Year & \multicolumn{1}{c}{ Institutions } & \multicolumn{1}{c}{ Functions } \\
\hline Thailand & 1997 & $\begin{array}{l}\text { Financial Sector } \\
\text { Restructuring Agency } \\
\text { Asset Management } \\
\text { Corporation }\end{array}$ & $\begin{array}{l}\text { To manage and sell } \\
\text { bad assets of the } \\
\text { financial sector }\end{array}$ \\
Indonesia & 1998 & $\begin{array}{l}\text { Indonesian Bank } \\
\text { Restructuring Agency }\end{array}$ & $\begin{array}{l}\text { To take over } \\
\text { management of weak } \\
\text { banks for disposal of } \\
\text { non-performing assets } \\
\text { of the banking system. }\end{array}$ \\
Korea & 1997 & $\begin{array}{l}\text { Korean Asset Management } \\
\text { Corporation }\end{array}$ & $\begin{array}{l}\text { To buy impaired assets } \\
\text { from banks. }\end{array}$ \\
\hline
\end{tabular}

The IMF injected about a $\$ 30$ billion loan on long term basis into the economies of the region to implement the desired reforms in the financial and capital markets. This assistance was seemingly aimed at filling the gap emanating from reduced foreign private capital inflows in the Southeast Asian economies (Thomas, 1998). It is well documented that no economy has come out of the financial crisis induced slump without undergoing systemic bank restructuring. IMF research on Mexican and other universal banking crises shows that, on average, output growth takes about three years to return to the early trend and the average cumulative loss in output growth is 11.2 per cent points following a crisis (Surez \& Weisbrod, 1993).

Rubin (1998, April 14) has urged that new multilateral arrangements are needed to foster three key objectives. The objectives include improving transparency through more extensive disclosure of financial and economic 
liabilities and capital flows; strengthening the regulation of financial institutions in emerging economies; and developing the role of the private sector in bearing an appropriate share of the burden in times of crisis. Indeed, prompt remedial action is among the key ingredients of successful banking reform. The countries making substantial progress took actions within a year of the emergence of their banking problems. They also effectively diagnosed the nature and extent of the problems, identified the underlying causes, and designed a restructuring strategy to address them all systematically. Systemic problems had multiple causes. The chances for success of solutions were the greatest when the causes were diagnosed accurately, then addressed swiftly and comprehensively (IMF, 1998, June).

In order to avoid any further economic and banking damages there may be complete transformation of the banking and financial system. Measures may include renewed attention to overall corporate strategy; advanced operational and personnel management and accounting systems; improved credit assessment and approval techniques; and appropriate monetary and fiscal policies (Wall Street, 1998). Other measures are convenient exchange management, innovation in common and advanced banking practices along with government guaranties, terminating malpractice in the banking industry, especially embezzlement, corruption, money laundering and fraud. 256 banks and financial institutions were closed down on the orders of IMF on the charges of corruption and embezzlement (IMF, 1997). Efforts were made to strengthen the health and competitiveness of the banking system by recapitalisation and restructuring of nationalised and commercial banks, increasing their autonomy and accountability and improving prudential regulations and the supervision of all financial institutions.

Proper banking regulation and supervision are indispensable instruments to avoid any further banking and economic crisis. Sound macroeconomic and regulatory policies would enable the potentially involved countries to successfully overcome financial emergencies. Hausmann (1995) stresses the importance of financial market transparency and business ethics in order to avoid a crisis.

Economic recovery prospects of the ASEAN countries are shaped by developments in Japan, China and the Western industrial countries. Japan, as the biggest source of demand and capital for the East Asian region, could play a pivotal role in the recovery if it could put its own economic house in order. Stimulating the growth of Japan will increase the absorption of exports from its ASEAN neighbours (Hussain, 1998). The U.S. and Europe, along with Japan, are likely to continue to be the major sources of short and long-term foreign investment for the East Asian region. Macroeconomic and monetary 
conditions within these countries substantially shape the strength of demand of exports from crisis countries. All economies in East Asia are now in the process of transition. The affected countries are taking decisive steps to tackle their banking difficulties (Payne, 1998). The countries with good growth rates are prone to sudden outside events, such as the collapse of export prices or higher world interest rates. In this regard, South Korea, Malaysia, Thailand, and Singapore are likely candidates for any banking and financial crisis.

Table-13: Future Economic Scenario of Selected ASEAN Economics

\begin{tabular}{lcc}
\hline \multicolumn{1}{c}{ Country } & $\begin{array}{c}\text { Per Capita GDP } \\
\text { Year - 1998 }\end{array}$ & $\begin{array}{c}\text { Per Capita GDP } \\
\text { Year - 2010 }\end{array}$ \\
\hline South Korea & 12,995 & 28,090 \\
Malaysia & 10,680 & 21,640 \\
Thailand & 6,285 & 12,405 \\
Singapore & 28,565 & 58,035 \\
\hline
\end{tabular}

Source: (Asia Week, 1999, August 20-21, p. 93) and (Far Eastern Economic Review, June 4, 1998).

Table-14: GDP Growth Estimates

\begin{tabular}{lccc}
\hline \multicolumn{1}{c}{ Country } & Year-1998 & Year-1999 & Year-2000 \\
\hline South Korea & -5.8 & 6.5 & 5.5 \\
Malaysia & -6.7 & 2.4 & 6.5 \\
Thailand & -9.4 & 4.0 & 4.0 \\
Singapore & 0.3 & 4.5 & 5.0 \\
China & 7.8 & 6.6 & 6.0 \\
Hong Kong & -5.1 & 1.2 & 3.6 \\
Indonesia & -13.7 & -0.8 & 2.6 \\
Japan & -2.8 & 1.0 & 1.5 \\
Philippine & -0.5 & 2.2 & 3.5 \\
Taiwan & 4.9 & 5.0 & 5.1 \\
\hline
\end{tabular}

Source: (IMF, 1999, June). 


\section{Economic and Banking Crises in Sweden and Mexico}

Sweden and Mexico suffered from economic and financial crises in the early 1990s. They were able to rescue their economies through a number of reforms and strategies.

\section{Sweden}

The banking crisis in Sweden started in late 1990. The main causes of the banking crisis were over-lending to the real estate sector. The loans were sunk due to the prevailing recession in the real estate industry. The government took quick action and stepped in with capital injections and loan guarantees. Many domestic banks were closed owing to their inability to handle and recover their non-performing loans. Sweden extended institutional support to rescue the suffering banks.

Table-15: Functions of Bank Support Authority: Sweden

\begin{tabular}{lcll}
\hline Country & Year & \multicolumn{1}{c}{ Institutions } & \multicolumn{1}{c}{ Functions } \\
\hline Sweden & 1992 & $\begin{array}{l}\text { Bank Support } \\
\text { Authority (BSA) } \\
\text { the lead } \\
\text { restructuring } \\
\text { agency. }\end{array}$ & $\begin{array}{l}\text { To charge with approving all } \\
\text { bank requests for guarantees, and } \\
\text { most banks set up workout } \\
\text { subsidiaries to deal with their } \\
\text { non-performing loans, freeing } \\
\text { bank management to deal with } \\
\end{array}$ \\
& & core business. \\
\hline
\end{tabular}

Source: (World Bank, 1992).

In December 1992, the Swedish Parliament guaranteed that their banks' obligations would be met by the government and set up a new Bank Support Authority (BSA) as the leading restructuring agency. Firm standards were set to determine which banks could and could not be saved. The BSA was charged with approving all bank requests for guarantees. Most banks set up workout subsidiaries to deal with their non-performing loans, freeing bank management to deal with core business.

Sweden weathered a severe banking crisis in the early 1990s. The Swedish government successfully came out of the potentially disastrous banking crisis through numinous political commitment, managerial skills, entrepreneurship qualities, better financial and economic policies, closed and better regulation, supervision system which was transparent and accountability, and a set of comprehensive restructuring strategies. In order to save the interests of the common populace the Swedish government paid the 
cost of the guarantees and supplied capital injections from the budget as needed. At its peak, the government's total banks, few in number, actually used government assistance (Dziobek \& Pazarbasioglu, 1997). Ultimately, the cost to the budget reduced to 4.2 per cent of GDP, and is declining over time through loan recoveries and sales of appreciated shares of the now-profitable state-owned bank, Nord Banken. With no applications for support received in 1994-96, the guarantee programme was abandoned (IMF, 1991). Now economic conditions are stable and there is about $\$ 19$ billion indirect foreign investment in Sweden (The Economist, 1999, October 2).

\section{Strategies and Reforms}

- Addressing the situation of bad loans and non-performing loans in order to sustain the element of profitability and solvency.

- Solving the immediate problems of weak and insolvent banks

- Eliminating shortcomings in the accounting, legal, and regulatory framework.

- Tightening lax supervision and compliance.

- Minimising the element of corruption along with comprehensive monetary and fiscal management implementation.

- Extending liquidity support to viable banks.

- Renewed attention to business strategy, improved management systems, and better credit assessment and approval techniques.

- Closed supervision and prudential regulations.

- Operational restructuring.

- Financial restructuring in attempting to restore solvency (World Bank, 1992; IMF, 1992).

\section{Mexico}

One of the worst economic crises emerged in December 1994 following the sharp peso devaluation and the subsequent decision by the Mexican authorities to let the peso float. As a result, foreign investment fled, international bond prices plummeted and the country experienced its worst financial crises in contemporary history (World Bank, 1995).

Michel Camadessus, the former Managing Director of the IMF, described the Mexican crisis in 1994-95 as the "the first financial crisis of 
the twenty-first century," keeping in view the volume and velocity of capital flow involved, (Martinez, 1998), "with comprehensive and systemic efforts Mexico is on the road to recovery". Mexico, a market-based economy with large elements of state ownership, especially in energy and heavy industry, had major successes by the early 1990s after being hurt badly by the 1980 s Latin American debt crisis. There was very high current accounts deficit before the crisis in Mexico as given in Table-16.

Table-16: Timeline of Current Deficit Accounts (Percent of GDP)

\begin{tabular}{lccc}
\hline Country & $\begin{array}{c}1992 \\
\text { Current Accounts } \\
\text { Deficit }\end{array}$ & $\begin{array}{c}\text { Current Account } \\
\text { Deficit }\end{array}$ & $\begin{array}{c}1994 \\
\text { Current Accounts } \\
\text { Deficit }\end{array}$ \\
\hline Mexico & -6.7 & -5.8 & -7.0 \\
\hline
\end{tabular}

Source: IMF and Bank of Mexico (1995).

The crisis caused currencies to depreciate, share prices to drop, and interest rates to soar in the country as shown in Table- 17 .

Table-17: Changes in Currency, Share Price Index and Interest Rate (December 2, 1994 to March 31, 1995)

\begin{tabular}{lccc}
\hline Country & $\begin{array}{c}\text { Depreciation of } \\
\text { the Currency Vis- } \\
\text { à-vis the Dollar } \\
\text { (Percent) }\end{array}$ & $\begin{array}{c}\text { Changes in the } \\
\text { share price index } \\
\text { (Basic Points) }\end{array}$ & $\begin{array}{c}\text { Changes in the } \\
\text { interest rates } \\
\text { (Basic Points) }\end{array}$ \\
\hline Mexico & 98.12 & -28.12 & 5,875 \\
\hline
\end{tabular}

Source: Blooming Financial Services L.P. and Bank of Mexico (1995).

The IMF, US government and Mexican authorities worked together to deal with the crisis. A comprehensive set of strategies was adopted and it dramatically reduced inflation, restarted strong economic growth and made good reductions in its fiscal deficit. The IMF and the U.S. total package was $\$ 50.5$ billion. As of February 1998, the Mexican government estimated the cost of all its bank rescue programmes to be 545.7 billion pesos (approximately \$55 billion based on the exchange rate in December 1998 (Barney, 1994). Mexico received a total of US\$12.1 billion as aid in 1997. The amount was a record high that signifies an increase of about 50 per cent in volume compared to that of 1996 (U.S. Embassy, 1993, April). 
The fiscal cost of supporting the financial system is estimated at 14.4 per cent of GDP for 1997 and is amortised over 30 years during the life of the programmes. The measures adopted were certainly costly. However, the results have been encouraging. Although GDP declined by 6.2 per cent in 1995, it has recovered, with growth rates of 5.2 per cent in 1996 and 7 per cent in 1997, being the highest rate in 16 years. Inflation fell from 52 per cent in 1995 to 15.7 per cent in 1997 and it continues to decline (World Bank, 1994).

The current account deficit, which averaged 6.7 per cent of GDP in 1992-94, was reduced to an average of 1.5 per cent of GDP in 1995-97. The trade balance was 6.1 per cent in 1998-99 (The Economist, 1999, October 2). The floating exchange rate has functioned well. International reserves increased by more than $\$ 25$ billion from January 1995 to January 1998. Total net public debt declined from 39 per cent of GDP in 1995 to 27 per cent in 1997 (Financial Industry Issues, 1998).

\section{Causes}

- The causes of Mexico's banking crisis were the result of interrelated deterioration of the banking and financial systems. The fragility of the Mexican banking system played a crucial role in the peso crisis of 1994-95.

- In many cases, inexperienced bank ownership and management and in some cases alleged fraud, coupled with the impact of the economic collapse on borrowers' repayment capacity, caused massive loan defaults in 1994-95.

- Inefficient operations or fraudulent activities in the banking sector.

- Negative role played by the multinational companies.

- Banking supervisory system, regulations, and accounting policies and procedures were inconsistence with international standards. Also transparency and accountability was not followed in cases of lending.

- Macroeconomic policies were not implemented on time in response to the wave of the overall crisis in Latin America.

- Poor financial disclosure and underdeveloped securities markets.

- Unproductive state-owned enterprises (Gavin \& Ricardo, 1996; Surez \& Weisbroad, 1994). 


\section{Strategies and Reforms}

- Operational restructuring including reduction of the cost of banking operations and decreasing the number of staff.

- Supervision and compliance according to recognised international standards.

- Granting autonomy to the central bank to function independently.

- Solving the immediate problems of weak and insolvent banks and improving the entire deteriorating banking industry.

- Policy makers in Mexico first addressed the situation of bad loans and non-performing loans in order to sustain the element of profitability through various programmes of privatisation and foreign investment.

- Eliminating shortcomings in the accounting, legal and regulatory framework.

- Minimising the element of corruption along with comprehensive monetary and fiscal management implementation.

- Better business strategy, improved management systems, and better credit assessment and approval techniques.

- Prudential regulations.

- Restoration of profitability and solvency of the banks and financial institutions.

- Emphasising fiscal prudence and stabilised monetary policy.

- Intensifying efficient corporate governance practices in the banking system.

- Establishing the element of transparency practices in bank accounting, disclosure and self-regulation (U.S. Embassy, Mexico, 1993, April 3; World Bank, 1995-96).

\section{Conclusion}

While mankind is living in the realm of 'survival of the fittest,' individuals and communities must be fit in body and in mind. However, evolution processes have transformed the fitness of body and mind into the collective wisdom and performance of communities as reflected in their 
soundness of policies and strategies, sophistication of production processes, core competencies of industries, and competitiveness of institutions.

In this world everything is connected with everything else. In this regard, economics, culture, environment, production systems, and financial institutions are connected with one another in a circular cause and effect relationship. Therefore, survival is also related to our ability to live in harmony with nature and other communities. Similarly, survival lies in producing environmentally safe products, creating sound alliances with international communities and institutions, promoting sustainable growth patterns, and following balanced trade pursuits.

Survival is in creating a whole greater than the sum of its parts, delivering value to others, devising new and improved ways to address the problems of human settlements, producing unity through diversity, and encouraging meaningful roles for the members of society beyond caste, colour and other ethnic divisions.

Survival is in the vitality of our culture and in the potency of our ideals of freedom, work, goodness, healthy living, equity, sovereignty, and respect for fellow human beings, air, water, soil, and even animals. Fitness is also in the adequacy of our emotions for pride and prejudice, cooperation and competition, war and peace, love and hatred, sorrow and joy, give and take, trust and deception, control and energy, sum and parts, time and space, and alienation and co-existence. The way of survival goes with the dynamism of waves, the freshness of a pure breeze, agility of new blood, domination of lively ideas, and force of action.

Banking and financial institutions and economic systems of Pakistan such as that of ASEAN and other crisis - hit countries, suffer from bad loans, political interference, corruption, declining exports, budget and trade deficits, internal and external debts, crashes of stock exchanges, currency mismanagement, and double digit inflation.

The crisis in East Asia was the inevitable consequence of an overvalued currency, massive bad bank loans, internal \& external debts, unstable exchange rates, large current account deficits, and short-term capital inflows. Lack of regulatory and supervisory traditions, corruption, poor management, inappropriate role played by multinational companies, prevalence of speculative culture, and non-transparent financial systems also played their parts in promoting the crisis.

The crises in East Asia, Sweden and Mexico have highlighted the importance of sound macro and micro-economic management. The crises 
have asserted the significance of integrated sets of policies and strategies for output, trade balance, interest rates, financial systems, appropriate exchange rate arrangements, prudent supervisory and regulatory practices, prevalence of accountability, and transparency along with banking and financial competitiveness and adaptability. Lessons of survival may include the following strategies and reforms:-

Macro Economic Strategies Reforms

Political and economic stability

Balanced policies of liberalisation, deregulation and privatisation

Coherent monetary and fiscal policies integrated with external factors

Only wise government intervention

Abandoning import monopolies of certain families, groups, or communities

Optimal allocation of budgetary resources

Adequate legal structures

Independence of central banks

Micro Economic Strategies and Reforms

Sound corporate governance

Equal opportunity for every member of the business community

Proper utilisation of economic resources in productive channels such as industry and banking rather than real estate business and golf clubs

Elimination of corruption

International Strategies and Reforms

Careful allowance of feasible foreign direct and indirect investment

Productive roles of multinationals companies

Prudent lending and use of funds from the international monetary agencies such as the World Bank and IMF

Financial and Banking Strategies and Reforms

Low debt-equity ratios 
Adequate accounting standards

Effective system of credit valuation

Minimising credit management risks

Minimising the possibility of non-performing loans

Integration between national and international financial markets

Reducing vulnerability to reciprocating capital flows

Importance of banking and financial restructuring

Development of securities markets

Discouraging speculation in stock exchanges and assets investments

Sophisticated bankruptcy laws

The economic and banking crises across countries underline that banking institutions can play a special role for the consistent growth, maintenance of financial system and health of business enterprises. A prompt and comprehensive action package may prove an effective instrument in the restoration of delinquent banking and financial systems.

Invariably, every crisis is the product of poor policy-making, inattention to serious problems in banking operations, and carelessness in monitoring and regulating financial systems. Also, the confidence of people in the sagacity of economic policies and efficacy of financial systems is critical. In the countries of East Asia, Mexico and Sweden, a central factor triggering each crisis was the decision by private investors and lenders to suddenly withdraw their money, investments and loans, from these markets. The wave of the economic crisis travelled to other countries like a virus in human systems.

Appropriate measures may be adopted to reduce the risks that reciprocating capital flows can create. Macroeconomic variables may be carefully analysed with balanced monetary and fiscal policies integrated with foreign trade factors. It is very important to improve the standards of supervision, regulation, and transparency of financial systems in this connection, a central bank may be given a free hand through more autonomy. Consolidation of the credit markets, liberalisation of interest rates, application of prudential regulations, and sensible administration of privatisation policies may be useful in order to avoid a banking and financial crisis in Pakistan. 
Everything in the world has a price and economic and banking reforms are no exception. Banking and economic reforms may be ineffective without cultural and social transformation. Personal interests and discretionary powers are to be replaced by national and organisational goals, sets of well defined laws and sound policies, and convenient procedures to efficiently process business transactions.

Countries may ensure the commitment of political leadership, soundness of financial systems, efficacy of economic policies, profitability of production channels, and feasibility of exchange rates in order to be fit for survival. Serious efforts may be made to resolve economic and financial anomalies at the national level and then integrate national economic interests with regional and global economies in order to increase the chances of survival.

The beneficiaries of the study include banking and finance experts, policy makers, management of multinational companies, and related researchers. Future study may attempt to develop generalised models for the survival of nations against economic and financial crises. 


\section{References}

Allan, F. \& Gale, D., 1997, Bubbles and Crisis. Cambridge Press.

American Chamber of Commerce, 1994, 'Charting the Economy'.

Asian Development Bank, 1999, 'Economic Outlook of Asia'.

Asia Week, 1998, May 26. Depreciation of Currencies.

Asian Development Bank, 1998, Asian Development Outlook 1997-98.

Aziz, S. 1998, May 27. Lessons of the Asian Crisis. The Dawn.

Barney, S.S., 1995, Mexican Banking System. Mexico Federal Banking Press.

Belchere, M., 1999, September 1. The News.

Bhagwati, J., 1998, March 25. 'The Capital Myth'. Financial Times.

Bermake, B., 1983, Non-Monetary Effects of the Financial Crisis in the Propagation of the Great Depression. American Economic Review. Vol. 73, pp. 257-276.

Baker, C.J., 1998, International Finance. Prentice Hall, Inc.

Blooming Financial Services L.P. and Bank of Mexico, 1995. 'The Crisis and Depreciation of Currency.'

Caprio, A., Gerad, S. and Klingebie1, N., 1996, 'Bank Insolvencies: CrossCountry Experience'. Policy Research Working Paper 1620. World Bank.

Caprio, A. \& Gerard, M., 1997, Safe and Sound Banking in Developing Countries. Research and Public Policy. No. 9, pp. 79-97.

Choi, B.Y., 1998, On Financial Crises in Korea. Korea Observer. 39(3).

Dziobek, C. \& Pazarbasioglu, C., 1997, 'Lessons from Systemic Bank Restructuring' UNCTAD Secretariat.

Davies, G., 1998, February 2. 'Causes, Cures and Consequences of the Asian Economic Crisis'. Economic Policy Institute. 
Dewatripont, M. \& Tirole, J., 1994, Banking Crisis and Regulation of the Banks. MIT Press

Demirguc, K. Asli, H. and Enrica, D., 1998, The Determinants of Banking Crises in Developing and Developed Countries. International Monetary Fund Staff Papers, 45(1): 81-109.

Far East Economic Review, 1998, June 4.

Feulner, J.E., 1998, 'The IMF Needs Real Reforms, Not More'. The IMF.

Fischer, S., 1998, September 10. Economic Crises and the Financial Sector. Financial Industry Issues. Fourth Quarter.

Gavin, M. \& Ricardo, H., 1996, The Root of Banking Crisis. The macro economic Context. In Hausman and Rojas- Suarez (eds.). Banking Crisis in Latin America. Pp. 27-63.

Goldstein, M. \& Philip, T., 1996, Banking Crisis in Emerging Economy: Origin and Policy Option. BIS Economic Paper. No. 46.

Gart, A., 1993, Regulation, Deregulation. John Wiley \& Sons, Inc.

Hussain, S.M., 1998, May 4-10. Should Japan be allowed to crash? The Dawn.

Hudson, M. \& Totten, B., 1998, Vulture speculators. Our World No. 197.

Haque, U.N., 1998, The Asian Crisis. The Dawn.

IMF, 1992, World Economic Outlook.

IMF, 1998, April. World Economic Outlook.

IMF, 1998, Asia crisis and depreciation of currencies.

IMF and Bank of Mexico, 1995, Economic Development and Current Accounts Deficits of the World.

IMF Report, 1998, June. Finance \& Development of Asian Countries.

IMF Report, 1998, Economic Growth of the Asian Countries.

International Labour Organisation, 1998, April. The Social Impact of the Asian Financial Crisis. 
Institute of International Finance, 1998, Asia and Growth Rates.

Johnson, S., Ellis, P. and Stiff, D., 1998, April. High-Tech Industries are Fueling U.S. Review of the U.S. Economy, No. 34.

Jeeman, J. \& Won, J.L., 1997, Recent Financial Reforms in Korea: IMF.

Khan, A.A., 1998, East Asian Currency and Economic Crisis (Editorial). The Institute of Banker in Pakistan. 64(1). Pp. 3-6.

King, M., 1994, Debt Deflation: Theory and Evidence. European Economic Review. Vo1. 38. Pp. 419-445.

Kiyotakei, N. \& More, J., 1997, Credit Cycle. Journal of Political Economy. Vol. 105 .

Kaminsky, G. \& Carmes, R., 1996, The Twin Crisis: The Causes of Banking and Balance of Payment Problems. World Bank.

Latin American Weekly Report, 1996, July 25, p. 333).

Lissakers, K., 1998, October 8. The IMF and the Asia Crisis. P. 2. IMF.

Mehran, H., 1996, Monetary and exchange system reforms in China, IMF Occasional. Paper, No. 141.

Martinez, O.G., 1998, What Lessons Does the Mexican Crisis Hold for Recovery in Asia? Institute of Banker in Pakistan. 64(3).

McCall, C.H., 1998, Financial Support to East Asian Countries Since 1997. The World Bank Report.

Moegan, J.P., 1998, April 24. Asian Markets after the Crisis. Asian Financial Markets Issues.

Payne, I., 1998, The Asian Turmoil. Institute of Banker in Pakistan. 64(4).

Poon, P.J., 1998, October. The Asian Economic Crisis What Happened. Policy Paper Oxfam International.

Lyle, R., 1998, July 17. Financial Development and Economic Growth. Journal of Economic Literature 35(2): 688-726.

Roach, S.S., 1998, February. The Global Economy Turned Inside Out? Washington Modern Library. 
Rubin, E.R., 1998, April. 'Strengthening the Architecture of the International Financial System’ Brookings Institution.

Robert, W.m 1998, August 4. The Asian Debt-and-Development Crisis of 1997-98. Causes and Consequences. World Bank.

Salemm, F., 1998, January 12-18. What was Wrong in Southeast Asia? The Dawn.

Shirazi, K.J., 1998, 'The East Asian Crisis: Orgins, Policy Challenges, and Prospects'. The World Bank.

Shelby, K. \& Davis, C., 1998, The Nature of the South Asian Countries. The Heritage Foundation.

Stearns, B., 1998, Apri1 14. Global Development Finance. World Bank.

Scott, E.R. \& Rothstein, J., 1998, American Jobs and the Asian Crisis: The Employment Impact of the Coming Rise in the U.S. Trade Deficit. Economic Policy Institute.

Stijn, C. \& Thomas, G., 1997, Are Financial Sector Weaknesses Undermining the East Asian Miracle? World Bank.

Stiglitz, J., 1998, The East Asian Crisis and Its Implications. Quarterly Journal of Economics 101 (May): 229-64.

Stiglitz, J., 1998, February 4. Bad Private-Sector Decisions. Wall Street Journal.

Surez, R.L. \& Weisbrod, S., 1994, Financial Fragility in Latin America in the 1980s and 1990s. BIS Basle.

Steams, B., International Labour Organisation, and International Monetary Fund, Institute of International Finance, 1998. Press Reports.

The South China Morning Post, 1997, November 3.

The New York Times, 1999, March 19.

The Financial Times, 1996, October 28. More Time and Money Needed. p.3.

Thomas, M.H., 1998, The International Community's Response to the Asian Financial Crisis. Economic Review. Second Quarter. 
The New York Times, 1999, March 19. The Reverse Domino.

The Economist, 1999, January 30. A Survival Guide. Pp. 58-59.

The Economist, 1999, October 2. Hot Property. P. 94.

The Economist, 1999, October 2. Emerging Market Indicators. P. 124.

The Economist, 1999, October 2. Economic Indicators. P. 123.

Toole, K., 1999, March 17. Banking reforms in Asia beginning to take shape. World Bank.

The News week, 1998, June 22.

U.S. Department of Commerce, 1998, United States and Asian Crisis.

U.S. Embassy, Mexico, 1993, April 3. Mexico Economic and Financial Report. Pp. 211-248.

Wall Street Journal, 1998, April 15. Editoria1.

World Bank, 1982, World Development Report.

World Bank, 1992, World Development Report.

World Bank, 1994, World Development Report.

World Bank, 1995, World Development Report.

World Bank, 1996, World Development Report.

World Bank, 1997, World Development Report.

World Bank, 1999, World Development Report.

Weisbrod, R.S., 1998, Liberalised financial markets can flourish. International Bank for Development.

Wijnholds, B.O., 1999, March 1. Maintaining an Indispensable Role. Financial Times.

Wolf, M., 1998, March 3. Flows and Blows. Financial Times. 